\title{
UPAYA MENINGKATKAN AKTIFITAS DAN HASIL BELAJAR PKN PADA MATERI PEMERINTAHAN KABUPATEN KOTA DENGAN MENGGUNAKAN METODE PENDEKATAN CTL (Contextual Teaching And Learning) SISWA KELAS IV SD NEGERI 6 LAWA TAHUN PELAJARAN 2016/2017
}

\author{
Oleh: SITI ASRA \\ Guru SDN 6 Lawa Kabupaten Muna Barat \\ Email : -
}

\begin{abstract}
Abstrak. Penelitian ini bertujuan untuk mengetahui efektivitas penerapan metode pembelajaran dengan pendekatan kontekstual (CTL) untuk meningkatkan aktivitas dan hasil belajar siswa pada materi Pemerintahan Kabupaten Kota di kelas IV SD Negeri 6 Lawa tahun pelajaran 2016/2017. Penelitian ini adalah Penelitian Tindakan Kelas (PTK), di mana guru yang bertindak sebagai peneliti yang juga mengajar di kelas IV yang diberi tindakan dibantu oleh seorang teman sejawat yang bertindak sebagai kolaborator atau observer yang bertugas mengamati aktivitas guru dan siswa selama proses pembelajaran dengan pendekatan kontekstual (CTL) berlangsung. Penelitian dilaksanakan di kelas IV semester 1 tahun pelajaran 2016 /-2017. Penelitian ini meliputi perencanaan, pelaksanaan tindakan, observasi dan refleksi. Kegiatan penelitian ini dilaksanakan dalam dua siklus yaitu siklus I dan siklus II. Sebelum dilakukan tindakan pra siklus dilakukan untuk mengetahui pelaksanaan pembelajaran yang belum menggunakan pendekatan kontekstual.Pada pra siklus di mana guru masih menggunakan metode pembelajaran konvensonal rata-rata nilai tes adalah 63,61 dan hasil ketuntasan belajar siswa masih 51,61\% dari 31 siswa yang mengikuti tes hanya 16 siswa yang tuntas. Aktivitas siswa pada pra siklus masih $40,65 \%$ dengan kategori kurang aktif. Pada siklus I, guru sudah melaksanakan pembelajaran pendekatan kontekstual (CTL) yang didapatkan hasil belajar siswa mendapatkan nilai rata-rata $68,39 \%$ dan ketuntasan belajar siswa masih $67,74 \%$ dari 31 siswa yang mengikuti tes ada 21 siswa yang tuntas belajar. Adapun aktivitas siswa pada siklus I sudah meningkat dari pra siklus yaitu 56,69 atau kategori cukup aktif. Walaupun aktivitas dan hasil belajar siswa dari pra siklus ke siklus I mulai ada peningkatan, tapi belum mencapai indikator yang diharapkan. Oleh karena itu tindakan dilanjutkan ke siklus II, di mana hasil belajar siswa rata-rata 75,10 dan ketuntasan belajar klasikal mencapai $87,10 \%$. Begitu juga aktivitas siswa pada siklus II juga meningkat yaitu 71,53 \% atau berkategori aktif. Dengan demikian pembelajaran yang berlangsung pada siklus II ini sudah dianggap berhasil karena sudah mencapai indikator.
\end{abstract}

Kata Kunci: Model Pembelajaran Kontekstual tipe CTL, Aktifitas belajar, Hasil belajar.

\section{A. PENDAHULUAN}

Proses pembelajaran yang

konvensional guru sangat mendominasi proses pembelajaran, sehingga siswa menjadi pasif dalam mengikuti kegiatan pembelajaran. Hal ini yang menyebabkan siswa takutmengungkapkan pendapatnya, ide-idenya karena siswa menganggapguru ngomong yang menakutkan. Proses pembelajaran yang terjadi di SD Negeri 6
Lawasaat ini pun masih menggunakan metode konvensional. Hal ini pula yang menyebabkan mereka bosan mengikuti proses pembelajaran yang diterapkan. Tanya jawab yang telah saya lakukan dengan beberapa guru mata pelajaran lain dan beberapa siswa, bahwasanya siswa sangat sulit atau sangat kurang dalam pelajaran PKN jadi nilai yang didapat masih kurang dari nilai maksimal. 
Sebelum melakukan proses belajar mengajar seorang guru harus menentukan suatu pendekatan yang akan digunakan agar tujuan pembelajaran yang telah disusun dapat tercapai. Pemilihan suatu pendekatan tentu harus disesuaikan dengan tujuan pembelajaran dan sifat materi yang akan menjadi objek pembelajaran. Pembelajaran kontekstual mengajak siswa belajar sambil bekerja dalam mempelajari ekosistem yang mereka lakukan di sekolah maupun yang dilakukan di luar sekolah. Pembelajaran yang mengajak siswa untuk belajar sambil bekerja akan mewujudkan pembelajaran yangbermakna bagi siswa. Pembelajaran yang bermakna akan membuatsiswa merasa bahwa apa yang mereka lakukan tidak sia-sia dan mereka mempunyai peran di dalam kegiatan pembelajaran.

Maka permasalahan yang muncul adalah bagaimana upaya guru untuk meningkatkan hasil belajar siswa dengan pendekatan yang tepat. Salah satu pendekatan pembelajaran yang dapat meningkatkan kreativitas siswa dalah pendekatan kontekstual. Dengan pendekatan kontekstual, siswa diarahkan untuk mengaitkan antara materi yang diajarkan dengan situasinyata siswa dan mendorong siswa membuat hubungan antara pengetahuan yang dimilikinya dengan kehidupan mereka sebagai anggotakeluarga dan masyarakat. Melihat hal tersebut, maka perlu dilakukan suatu penelitian untuk menemukan sebuah alternatif pemecahan masalah dalamupaya meningkatkan kualitas pembelajaran guna meningkatkan prestasi belajar siswa.

Menurut Depdinas (2002 : 29) Contextual Teaching and Learning (CTL) adalah suatu strategi pembelajaran yang menekankan kepada proses keterlibatan siswa secara penuh untuk dapat menemukan materi yang dipelajari dan menghubungkannya dengan situasi kehidupan nyata sehingga mendorong siswa untuk dapat menerapkannya dalam kehidupan mereka . Pada dasarnya saat ini kondisi yang ada di sekolahan kurang begitu maju dalam kegiatan belajar mengajar, pada umumnya guru hanya mengajar sesuai dengan kurikulum yang ada tanpa ada variasi apa pun. permasalahan yang terjadi saatini adalah kurang begitu bervariasi dalam menyampaikan materi sehinggaanak cepat bosan sehingga hasil belajar siswa kurang maksimal, untuk itu saya mencoba menyampaikan materi yang akan saya lakukan nanti yaitu dengan memberi sedikit variasi agar siswa tidak begitu jenuh dalam menerima materi yang akan disampaikan dengan cara melibatkan langsung siswa dalam materi yang akan disampaikan, dengan cara pendekatan CTL ini diharapkan siswa bisa lebih aktif dalam belajar karena pendekatan CTL itu sendiri 
adalah suatu strategi pembelajaran yang menekankan kepada proses keterlibatan siswa secara penuh untuk dapat menemukan materi yang dipelajari dan menghubungkannya dengan situasi kehidupan nyata sehingga mendorong siswa untuk dapat menerapkannya dalam kehidupan mereka

Dari konsep tersebut ada tiga hal yang harus kita pahami. Pertama, CTL menekankan kepada proses keterlibatan siswa untuk menemukan materi.Kedua, CTL mendorong agar siswa dapat menemukan hubungan antara materi yang dipelajari dengan situasi kehidupan nyata. Ketiga, CTL mendorong siswa untuk dapat menerapkannya dalam kehidupan.

Tapi pada kenyataannya yang ada di sekolah berbeda dengan teori yangada, bahwa siswa banyak yang monoton pada materi yang disampaikan oleh guru sehingga kondisi dalam pembelajaran tidak bisa hidup karena siswafakum dalam belajar. Untuk itu saya mencoba menerapkan pendekatan CTL dalam pembelajaran yang nantinya akan saya lakukan dalam penelitian.

Berdasarkan uraian di atas, peneliti yang juga selaku guru PKn di kelas IV SD Negeri 6 Lawa tertarik untuk melakukan penelitian bekerja sama dengan guru lainnya yaitu Ibu guru Wa Ode Hasni, S.Pd.I sebagi kolaborator/observer dalam menerapkan pendekatan CTL melalui
Penelitian Tindakan Kelas (PTK) yang berjudul "Upaya meningkatkan aktivitas dan hasil belajar Siswa pada materi Pemerintahan Kabupaten Kota dengan menggunakan metode pendekatan CTL (Contextual Teaching and Learning) di kelas IV SD Negeri 6 Lawa tahun Pelajaran 2016/2017.

\section{B. METODE PENELITIAN}

\section{Jenis dan Setting Penelitian}

Jenis penelitian ini adalah penelitian tindakan kelas (classroom action research) berdasarkan naturalistic kualitatif. Subyek penelitan ini adalah siswa kelas IV SD Negeri 6 Lawa semester I Tahun Pelajaran 2016/2017.

\section{Rencana Tindakan}

Tahap Perencanaan: Kegiatan ini diawali dengan orientasi, yaitu studi pendahuluan sebelum tindakan penelitian dilaksanakan. Berdasarkan hal tersebut di atas maka disusunlah rencana tindakan yang hendak dilaksanakan berupa rencana pelaksanaan pembelajaran (RPP) selama proses pelaksanaan pembelajaran PKN dengan menggunakan model pembelajaran kontektualtipe CTL.

Tahap Pelaksanaan Tindakan: Tahap pelaksanaan tindakan yaitu merupakan praktek pembelajaran yang nyata yang telah disusun sebelumnya. Tindakan ini ditujukan untuk memperbaiki keadaan atau proses pembelajaran. 
Observasi dan Evaluasi: Pada tahap ini obsever mengobservasi segala tindakan atau aktivitas yang telah dilakukan oleh guru dengan menggunakan lembar observasi dalam proses pembelajaran PKN dengan menerapkan model pembelajaran kontektualtipe CTL. Pada setiap akhir tindakan diadakan tes untuk mengetahui peningkatan hasil belajar setiap siklus yang dilakukan guru.

Tahap Refleksi: Refleksi ini dilakukan pada setiap akhir pelaksanaan tindakan yang dilakukan secara kolaboratif antara peneliti dengan observer atau teman sejawat. Dimaksudkan untuk menemukan dan merekonstruksi makna situasi sosial, serta untuk mendapatkan dasar bagi perbaikan pada rencana tindakan selanjutnya. Keempat tindakan tersebut dapat digambarkan dalam bagan sebagai berikut :

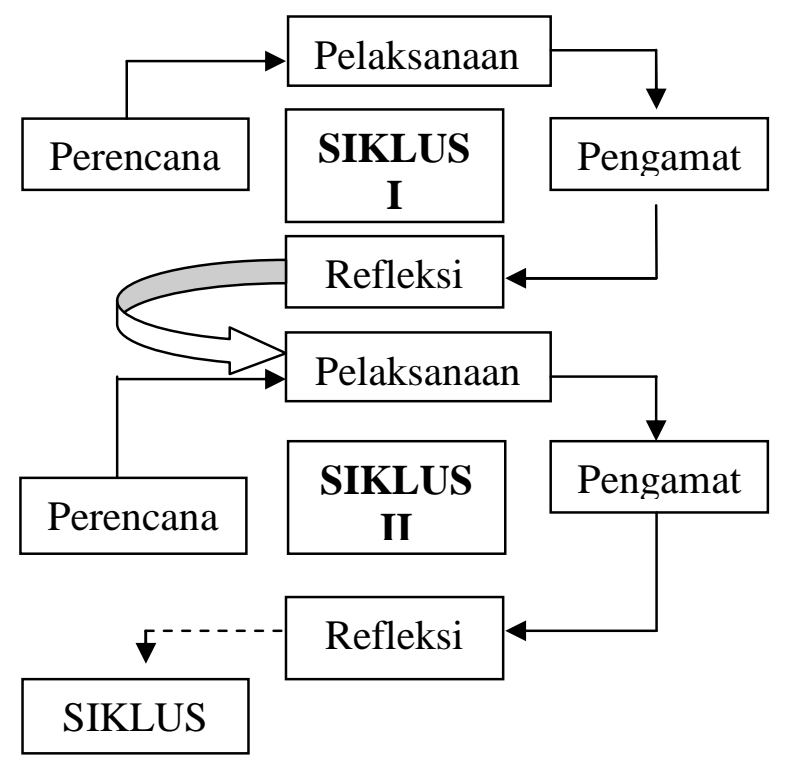

Gambar 1. Diagram alir model penelitian tindakan kelas

Data tentang pelaksanaan pembelajaran akan dianalisis secara deskriptif berdasarkan hasil observasi dari observer. Sedangkan data kuantitatif akan dianalsis dengan melihat hasil tes pada setiap akhir tindakan. Artinya apabila setiap akhir tindakan secara klasikal belum mencapai 80\% dari KKM maka akan dilanjutkan pada siklus berikutnya, sampai mencapai indikator kinerja yang telah ditetapkan.

\section{HASIL DAN PEMBAHASAN}

\section{Tindakan Pra Siklus}

Dalam pelaksanaan Pra Siklus ini, guru masih menggunakan metode konvensional dalam proses pembelajarannya. Maka dalam Pra Siklus ini, tidak menggunakan pembagian atau pembentukan kelompok. Dalam hal ini guru menguasai penuh proses pembelajaran. Pada pelaksanaan Pra Siklus materi yang disampaikan adalah tentang sistim pemerintahan. Setelah diadakan tes didapat nilai rata-rata kelas 63,61 , dengan banyaknya siswa yang tuntas hanya 16 orang dan yang tidak tuntas sebanyak 15 orang dengan ketuntasan belajar siswa secara klasikal adalah 51,61\%. Ini berarti sebagian besar siswa kelas IV tersebut belum dapat menyelesaikan evaluasi dengan baik. Begitu juga dengan. Aktivitas siswa kelas IV yang masih $40,65 \%$ atau masih kategori kurang aktif. Pada 
umumnya peserta didik masih takut salah, takut mengungkapkan pendapatnya karena guru sangat mendominasi jalannya proses pembelajaran. Begitu pula kinerja guru dalam proses pembelajaran yang masih menggunakan metode konvensional, berdasarkan hasil pengamatan masih $57,81 \%$ atau kategori cukup. Secara keseluruhan proses pembelajaran pada materi Pemerintahan kota di kelas IV dengan menggunakan metode konvensional dianggap tidak berhasil.

\section{Tindakan Siklus I}

\section{1) Perencanaan}

Setelah ditetapakn untuk menerapakan model Pembelajaran kontekstual tipe CTL pada materi tentang Sistem Pemerintahan, maka kegiatan selanjutnya adalah menyiapkan beberapa hal yang diperlukan dalam pelaksanaan tindakan tiap siklus. Adapun hala-hal yang dilakukan pada tahap ini adalah membuat RPP , menyiapkan materi yang akan didiskusikan sebagai sumber belajar dan LKS sebagai reverensi dan membuat alat evaluasi (soal tes) untuk melihat keberhasilan peserta didik dalam penguasaan kompetensi yang terdiri dari 5 soal esay.

\section{2) Pelaksanaan tindakan}

Melaksanakan pembelajaran sesuai dengan RPP yang telah disiapkan. Langkah yang ditempuh dalam pembelajaran dengan menggunakan pendekatan kontekstual (CTL) pada sub materi tentang Sistem
Pemerintahan. Kegiatan selanjutnya guru membagi siswa dalam beberapa kelompok belajar yang terdiri dari 5-6 siswa dalam satu kelompok. Mengarahkan siswa agar saling kerjasama dan saling membantu sesuai kelompoknya masing-masing. Meminta 1 atau 2 siswa untuk mendemonstrasikan temuannya (cara menyelesaikan masalah) di depan kelas. Dengan tanya jawab, dapat mengulangi jawaban siswa agar siswa yang lainnya memiliki gambaran yang jelas tentang pola pikir siswa yang telah menyelesaikan soal tersebut. Memberikan motivasi dan kesempatan kepada siswa untuk bertanya. Setelah itu, menyimpulkan materi yang telah dipelajari.

\section{3) Pengamatan}

Selama proses pembelajaran melakukan pengamatan untuk mengetahui aktivitas guru dan siswa dalam pelaksanakan pembelajaran.

\section{4) Refleksi}

Membuat simpulan sementara terhadap pelaksanaan siklus I. Berdasarkan hasil pelaksanaan Siklus I, dapat menunjukkan peningkatan dalam hal aktivitas guru dan siswa siswa serta hasil belajar siswa. Hal ini dapat dilihat dari peningkatan aktivitas guru, aktivitas siswa dan hasil belajar siswa dari pra siklus (sebelum penerapan pendekatan kontekstual) dibandingkan dengan Siklus I (setelah diterapkannya pendekatan 
kontekstual). Hasil belajar dalam pelaksanaan siklus I didapat nilai rata-rata 68,39, dengan ketuntasan belajar siswa secara klasikal 67,74\% dimana siswa yang tuntas sebanyak 21 orang dan yang tidak tuntas sebanyak 10 orang dari 31 jumlah siswa yang mengikuti tes evaluasi siklus I. Begitu jugadenganaktivitas guru dalam pelaksanaan pembelajaran dengan metode pendekatan kontekstual (CTL) juga mengalami peningkatan dari prasiklus yaitu pada siklus I mencapai persentase sebanyak $78,13 \%$ atau kategori baik. Sedangkan untuk aktivitas siswa pada siklus I diperoleh persentase sebanyak $56,69 \%$ atau kategori cukup baik. Peningkatan tersebut tidak lepas dari keseriusan peserta didik dalam mengikuti kegiatan pembelajaran. Terutama kerjasamanya dengan teman lain dalam kelompok untuk mengkonstruksi pengetahuannya untuk menemukan penyelesaian yang harus mereka selesaikan. Dalam proses penyelesaian masalah yang dihadapi, siswa mengeluarkan segala pengetahuannya untuk sharing antar teman dalam kelompok.

Walaupun dalam siklus I ini siswa masih belum bias secara maksimal dalam proses pembelajaran, terutama dalam hal mengeluarkan pendapatnya untuk menjawab pertanyaan dari guru maupun mengerjakan soal di depan (mendemonstrasikan hasil diskusi) karena masih takut salah atas penyelesaian yang mereka selesaikan. Walaupun dalam pelaksanaan siklus I aktivitas guru sudah mencapai indicator $\geq 75$ yaitu $78,13 \%$, tetapi aktivitas siswa masih 56,69\% dan hasil belajar siswa mencapai nilai rata-rata $56,69 \%$ serta ketuntasan hasil belajar $67,74 \%$. Dari aktivitas siswa yang hanya mencapai $56 \%$ dan nilai rata-rata tes siswa 68,39 serta ketuntasan belajar siswa secara klasikal 67,74\%, sehingga peneliti beranggapan bahwa hasil penelitian pada siklus I belum dianggap berhasil karena belum mencapai indikator yang telahditetapkanyaitunilai rata-rata $\geq 75$ dan minimal $85 \%$ siswamencapainilai $\geq 70$. Dengan demikian berdasarkan hasil dari pelaksanaan penelitian pada siklus I, guru berusaha melakukan perbaikan-perbaikan dengan pendekatan memotivasi agar siswa lebih bias percaya diri dalam mengeluarkan pendapatnya dan kemampuannya pada siklsu II. Pada pelaksanaan siklus I, hasil dan aktivitas belajar dapat dilihat dalam tabel 1 berikut;

Tabel 1. Tabel Hasil Pengamatan Siklus I

\begin{tabular}{lll}
\hline No. & Indikator & Hasil Pengamatan \\
\hline 1. & Aktivitas guru & $78,13 \%$ \\
2. & Aktivitas siswa & $56,69 \%$ \\
3. & Nilai rata-rata kelas & 68,39 \\
4. & $\begin{array}{l}\text { Ketuntasan belajar } \\
\text { siswa }\end{array}$ & $67,74 \%$ \\
\hline
\end{tabular}

\section{Tindakan Siklus II}

\section{1) Perencanaan}

Setelah ditetapakan untuk menerapakan model Pembelajaran 
kontekstual tipe CTL pada materi tentang Sistem Pemerintahan, maka kegiatan selanjutnya adalah menyiapkan beberapa hal yang diperlukan dalam pelaksanaan tindakan tiap siklus. Adapun hal-hal yang dilakukan pada tahap ini adalah membuat RPP , menyiapkan materi yang akan didiskusikan sebagai sumber belajar dan LKS sebagai reverensi dan membuat alat evaluasi (soal tes) untuk melihat keberhasilan peserta didik dalam penguasaan kompetensi yang terdiri dari 5 soal esay.

\section{2) Pelaksanaan Tindakan}

Melaksanakan pembelajaran sesuai dengan RPP yang telahdisiapkan sesuai revisi berdasarkan evaluasi pada siklus 1 . Langkah dalam pembelajarannya sama seperti pada siklus I. Dalam siklus II membahas tentang sub materi pemerintahan kota. Disini guru juga ikut berperan aktif dalam membimbing dan mengamati saat siswa belajar serta menjawab pertanyaan yang kira-kira siswa belum tahu guru bisa menjelaskan sekilas meskipun sebelumnya sudah dijelaskan.

Disini, siswa lebih dituntut lagi untuk mempresentasikan hasil diskusinya. Setiap kelompok mewakili satu anak maju untuk presentasi membahas hasil kerja kelompoknya. Ada beberapa anak yang mengajukan pertanyaan kepada setiap kelompok yang maju dan setiap pertanyaan dicatat guru untuk dibahas bersama-sama.
Setelah semua kelompok sudah mempresentasikan, maka guru disini berperan aktif dalam menjelaskan sub materi pemerintahan kota.

\section{3) Pengamatan}

Melakukan pengamatan yang sama pada seperti siklus I, dalam proses pembelajarannya guru bisa lebih tahu aktivitas siswa karena guru ikut andil dalam peran diskusi siswa, guru juga melakukan evaluasi di siklus II serta mencatat keberhasilan dan hambatan yang dialami dalam proses pembelajaran pada pelaksanaan siklus II.

\section{4) Refleksi}

Refleksi pada siklus II ini dilakukan untuk melakukan penyempurnaan metode pembelajaran dengan menggunakan pendekatan kontekstual (CTL) yang diharapkan dapat meningkatkan aktivitas siswa dalam proses pembelajaran dan hasil belajar.

Aktivitas belajar siswa pada siklus II lebih baik dibanding pada siklus I, hal ini dikarenakan siswa mulai terbiasa dalam pelaksanaan pembelajaran dengan pendekatan kontekstual. Disamping itu siswa mulai tumbuh kepercayaan diri dalam dirinya untuk bisa menyelesaikan masalah. Secara tidak langsung hal ini bisa membuat siswa tidak takut lagi salah, dan tidak takut lagi untuk mengeluarkan pendapatnya untuk menyelesaikan masalah. 
Aktivitas siswa dalam pelaksanaan siklus II mencapai $71,53 \%$ dan sedangkan aktivitas guru juga mengalami peningkatan yaitu $87,50 \%$. Ketuntasan hasil belajar siswa pada siklus II mencapai $87,10 \%$ dari 31 siswa yang mengikuti tes, jumlah siswa yang tuntas sebanyak 27 orang dan yang tidak tuntas ada 4 orang.Hal ini menunjukkan bahwa setiap siklusnya siswa mengalami peningkatan baik dalam hal hasil belajar maupun aktivitas siswa yang ditandai dengan meningkatnya nilai ratarata siswa dan ketuntasan dalam pembelajaran materi dan meningkatnya aktivitas siswa dalam kegiatan belajar mengajar. Pada pelaksanaan siklus II, hasil dan aktivitas belajar dapat dilihatdalam tabel 2 berikut;

Tabel 2 : Tabel hasil pengamatan siklus II

\begin{tabular}{lll}
\hline No. & Indikator & Hasil Pengamatan \\
\hline 1. & Aktivitas guru & $87,50 \%$ \\
2. & Aktivitas siswa & $71,53 \%$ \\
3. & Nilai rata-rata kelas & 75,10 \\
4. & Ketuntasan & $87,10 \%$ \\
& belajar siswa & \\
\hline
\end{tabular}

\section{PEMBAHASAN}

Berdasarkan hasil pengamatan aktivitas siswa dalam pembelajaran di kelas IV materi pemerintahan kota selama pembelajaran berlangsung secara keseluruhan diperoleh pada pra siklus persentase aktivitas siswa $40,65 \%$ sehingga, dapat dikatakan bahwa banyak siswa yang melakukan aktivitas dalam proses pembelajaran berkriteria kurang aktif. Pada siklus I persentase aktivitas siswa adalah 56,69\% sehingga, dapat dikatakan bahwa banyak siswa yang melakukan aktivitas dalam proses pembelajaran berkriteria cukup aktif. Pada siklus II persentase aktivitas siswa adalah 71,53\% sehingga, dapat dikatakan bahwa banyak siswa yang melakukan aktivitas dalam proses pembelajaran berkriteria aktif. Dari data di atas, kemudian divisualisasikan dalam bentuk histrogram seperti tampak pada grafik 1 berikut;

Grafik 1. Hasil pengamatan aktivitas siswa

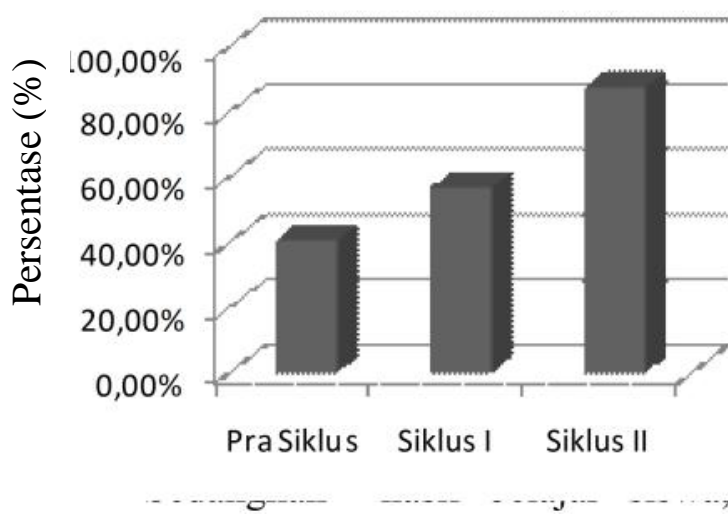

diperoleh perbedaan rata-ratanilai tes pembelajaran pada setiap akhir siklus. Adapun rata-rata tespembelajaran setiap siklus diperoleh data hasil tes pra siklus rata-rata nilai tes adalah63,61 dari 31siswa yang mengikuti tes, dengan ketuntasan belajar siswa 51,61\% (16 siswa yang tuntas dan 15 siswa yang tidak tuntas).Pada siklus I rata-rata nilai tes adalah 68,139 dari 31siswa yang mengikuti tes, dengan ketuntasan belajarsiswa 67,74\% (21 siswa yang tuntas dan 10 siswa yang tidak 
tuntas).Pada siklus II rata-rata nilai tes adalah75,10 dari 31 siswa yang mengikuti tes, dengan ketuntasan belajarsiswa 87,10\% (27 siswa yang tuntas dan 4 siswa yang tidak tuntas).Dari data di atas kemudian divisualisasikan dalam bentukhistrogram seperti tampak pada grafik 2 dan grafik 3 berikut;

Grafik 2. Hasil Nilai Rata-Rata Tes

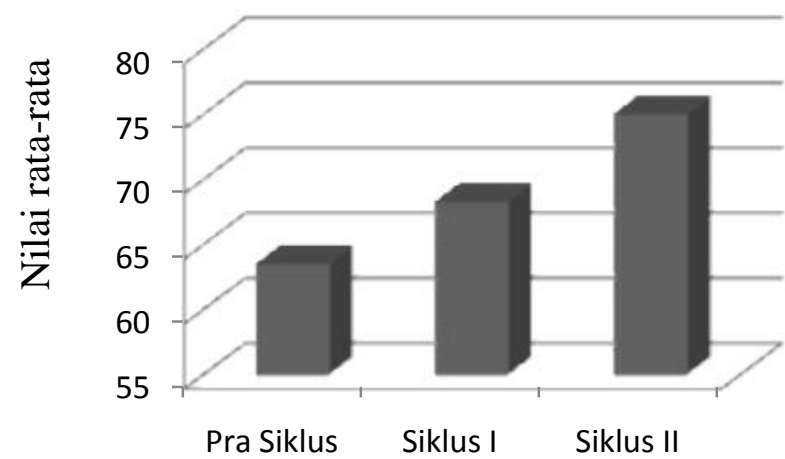

Grafik 3. Hasil nilai ketuntasan belajar siswa

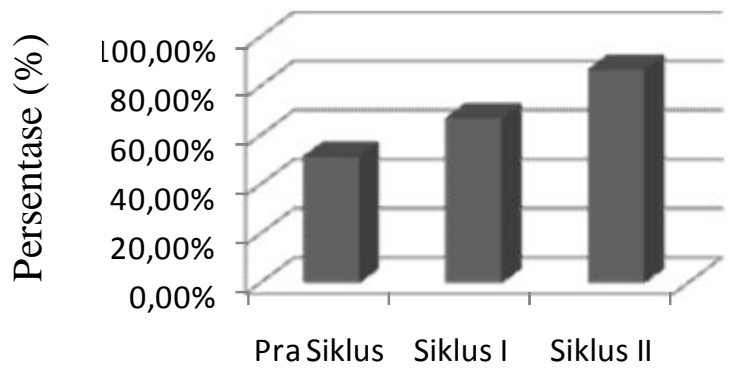

Berdasarkan hasil pengamatan aktivitas guru dalam pembelajaran di kelas IV pada materi pemerintahan kota selama pembelajaran berlangsung secara keseluruhan diperoleh data pada pra siklus persentase aktivitas guru 42,19\% sehingga, dapat dikatakan bahwa guru yang melakukan aktivitas dalam proses pembelajaran berkriteria cukup. Pada siklu I persentase aktivitas guru adalah $78,13 \%$ sehingga, dapat dikatakan bahwa guru yang melakukan aktivitas dalam proses pembelajaran berkriteria baik. Pada siklus II persentase aktivitas guru dalah $87,50 \%$ sehingga, dapat dikatakan bahwa guru yang melakukan aktivitas dalam proses pembelajaran berkriteria sangat baik.Dari data tersebut, kemudian divisualisasikan dalam bentuk histrogram seperti tampak pada grafik 4 berikut;

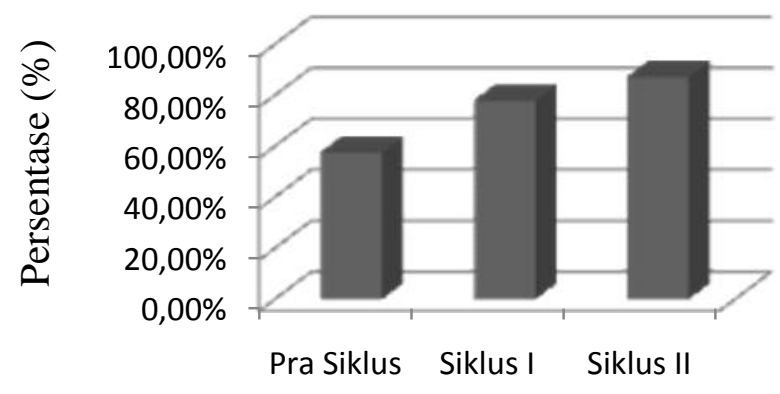

\section{KESIMPULAN}

Pada siklus II Aktivitas belajar siswa lebih baik dibanding pada siklus I, hal ini dikarenakan siswa mulai terbiasa dalam pelaksanaan pembelajaran dengan pendekatan kontekstual (CTL). Disamping itu siswa mulai tumbuh kepercayaan diri dalam dirinya untuk bisa menyelesaikan masalah. Secara tidak langsung hal ini bisa membuat siswa tidak takut lagi salah, dan tidak takut lagi untuk mengeluarkan pendapatnya untuk menyelesaikan masalah. Aktivitas siswa dalam 
pelaksanaan siklus II mencapai $71,53 \%$, sedangkan hasil belajar siswa juga mengalami peningkatan yaitu dengan nilai rata-rata 75,10. Siswa yang tuntas mencapai $87,10 \%$ dari31 siswa yang mengikuti tes, sebanyak 27 yang tuntas belajar dan yang tidak tuntas ada 4 orang.

\section{DAFTAR PUSTAKA}

Departemen Pendidikan Nasional. 2002. Pendekatan Kontekstual (Contextual Teaching and Learning (CTL)). Jakarta: Depdiknas.

Nana Sudjana. 2008. Dasar-Dasar Proses Belajar Mengajar. Bandung: Sinar BaruAlgensindo.

Oemar Hamalik. 2008. Proses Belajar Mengajar. Jakarta: Bumi Aksara.

Slameto. 1995. Belajardan Faktor-faktor yang Mempengaruhinya. Jakarta: Rineka Cipta.

Sugiyono. 2002. Metode Penelitian Pendidikan: Pendekatan Kuantitatif, Kualitatif danR \& B. Bandung: Alfabeta.

Syaiful Sagala. 2003. Konsep dan Makna Pembelajaran. Bandung: Alfabeta.

Suprihatiningrum, J. 2013. Strategi Pembelajaran : Teori dan Aplikasi. Jogjakarta: Ar-Ruzz Media.

Winasanjaya. 2006. Strategi pembelajaran berorientasi standar prosespendidikan. Jakarta: Kencana.

Wiriaatmadja, R. 2012. Metode Penelitian Tindakan Kelas. Bandung: PT. Remaja Rosdakarya.

Yudhistira, D. 2013. Menulis Penelitian Tindakan Kelas Yang Apik (Asli PerluIlmiah Konsisten). Jakarta: PT. Gramedia Widiasarana Indonesia. 